blishment which, the capital having no University, somewhat supplies the place of a national college and musuem, and which numbers among its staff the distinguished names of Donati in Astronomy, Maurice Schiff in Physiology, Ugo Schiff in Chemistry, Targioni-Tozzetti in Zoology, and Parlatore in Botany.

THE South I Kensington authorities have printed syllabuses of the courses of lectures already delivered at the Museum, under the title of "Instruction in Science and Art for Women." We have before us "Notes of fifteen lectures on Physics, by Professor Guthrie," and "Notes of ten lectures on Botany, by Professor Oliver." We commend both these programmes to lecturers on natural science, as models of what scientific lectures ought to be-thorough, exact, and yet popularly intelligible.

WE bave received a German edition, by Dr. Oppenheim, of Wurtz's History of Chemical Theory, from the time of Lavoisier to our own day.

The Paisley and Renfrewsirire Standard prints an unpublished letter of Wilson the ornithologist. It is dated Nashville, Tennessee, May Ist, 1810, and deals more with the manners and customs of the people than with his favourite science of Ornithology.

Mr. KeITH Johnston, jun., publishes a map of the Lake Region of Eastern Africa, showing the sources of the Nile, recently discovered by Dr. Livingstone. To it is appended an interesting account of the progress of discovery in the Lake Region, with notes on its physical features, climate, and population.

DR. J. LEon SOUBeiran has reprinted from the Annals of the Linnean Society of Maine-et-Loire an article on the herring fishery, which gives an account of the fishery from the earliest times in the different countries of Europe, and of the various modes of curing the fish.

THE Architect, for April 9, describes the projected new buildings for Owens College, Manchester. The designs for the first portion being now complete, the works will shortly be commenced on a site about a mile to the south of the centre of Manchester, on the west side of Oxford Road. The style of the building is Gothic, of a collegiate and early type.

C. G. EHRENBERG's "Gedächtnissrede auf Alexander von Humboldt," presented to the Academy of Sciences at Berlin, is a graceful centenary tribute to the memory of the great savant.

ThE Commissioners for the Annual International Exhibitions of selected works of fine and industrial art and scientific inventions have issued a code of rules for educational works and appliances produced in the United Kingdom, or produced abroad, but submitted to the British judges. We suspect that exhibitors will find it somewhat difficult to determine under which of the denominations named in the commissioners' list they should range themselves; this we find "philosophical instrument makers" and "optical instrument makers," with separate heading; for " microscope makers," "telescope makers," "stereoscope makers," \&c. We should hardly have thought that it would have been necessary to make arrangements for the special exhibition of objects under the heads of "coloured saucer makers," "pink saucer makers," "preparers of botanical specimens," "Ward's case makers," \&c. Everything intended for exhibition must be sent in by Wednesday, the 8 th of February, I 87 I.

M. ClOEz has detected in the leaves of Eucalyptus globulus, a tree which has been recently largely introduced into France for purposes of ornamentation, a substance extremely analogolis to camphor. Ten kilogrammes of fresh leaves give 275 grammes of this new substance, the formula for which is $\mathrm{C}_{24} \mathrm{H}_{20} \mathrm{O}_{2}$, and its boiling point $175^{\circ} \mathrm{C}$.

A Monthly journal has been started in Jena devoted to the interest of Sericiculture. We have before us the first number of the Seiden-bau Zeitung fiir Nord-deutschland; bearing the names of Dr. E. Hallier, H. Maurer, and J. Zorn, as Editors.

\title{
MADREPORARIA OF THE RED SEA
}

THE following table is required to complete Prof. Duncan's account in NATURE, No. 24, p. 6I2, of the Madreporaria dredged up in the Forcupine Expedition. The specific names given in the table are those finally adopted by Prof. Duncan :-

\begin{tabular}{|c|c|c|c|c|c|c|}
\hline Name. & No. & Latitude. & Longitude. & Depth. & Temp. & Remarks. \\
\hline 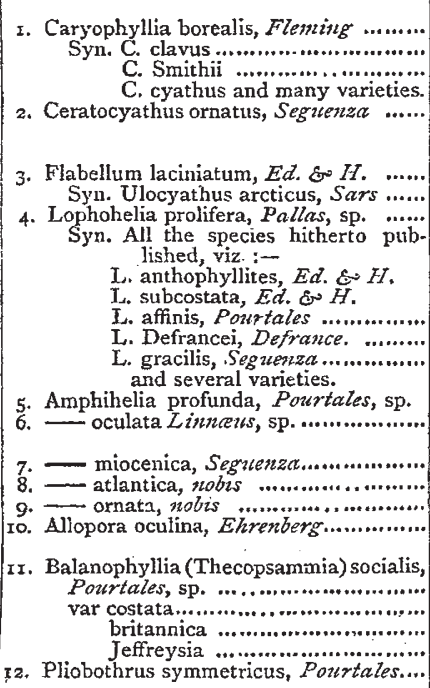 & $\begin{array}{r}3 \\
25 \\
5 \\
\\
13 \\
14 \\
15 \\
25 \\
54 \\
54 \\
54\end{array}$ & $\begin{array}{rrrr}51 & 51 & \mathrm{~N} \\
56 & 4 \mathrm{I} & \mathrm{N} \\
52 & 4 & \mathrm{~N} \\
& & \\
& & \\
53 & 42 & \mathrm{~N} \\
53 & 49 & \mathrm{~N} \\
54 & 5 & \mathrm{~N} \\
56 & 4 \mathrm{I} & \mathrm{N} \\
59 & 56 & \mathrm{~N} \\
& & \\
59 & 56 & \mathrm{~N} . \\
& \ldots . . . . .\end{array}$ & 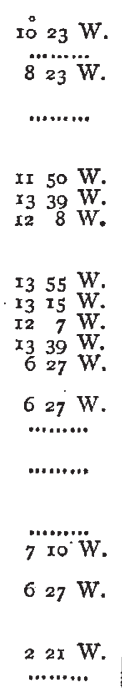 & $\begin{array}{c}208 \\
x 73 \\
422 \\
164 \\
363 \\
363 \\
\ldots \ldots\end{array}$ & $\begin{array}{c}49^{\circ} 6 \\
49^{-6} \\
47^{\circ} 0 \\
46^{\circ} 5 \\
3^{\circ} \cdot 5 \\
3^{\circ} \cdot 5 \\
\ldots \ldots \ldots . . .\end{array}$ & $\begin{array}{l}\text { Specimens very numerous. } \\
\text { The species is found in the coralliferous British seas and } \\
\text { Mediterranean. Fossils in Miocene and Pliocene of } \\
\text { Sicily. At great depths in Mediterranean (recent). } \\
\text { One specimen. Not known elsewhere; the genus is, with } \\
\text { this exception, extinct. The species is fossil in the } \\
\text { Sicilian Miocene. } \\
\text { Specimens numerous. } \\
\text { This is a well-knewn Norwegian recent form. } \\
\text { Specimens numerous. } \\
\text { The variability of this species at different depths is so great } \\
\text { that all the known species must in conseguence be con- } \\
\text { sidered varieties of one form. Recent in Norwegian seas, } \\
\text { Mediterranean, and off the Shetlands. Fossil in Miocene } \\
\text { and Pliocene deposits of Sicily. A variety is found off the } \\
\text { American coast. A considerable number of specimens was } \\
\text { found in the "cold area" at depths from } 500-600 \text { fathoms. } \\
\text { Many specimens. } \\
\text { The necessity for absorbing Diplohelic is stated in the fol- } \\
\text { lowing pages. } \\
\text { The species of Amphihelic range from the Miocene to the } \\
\text { present day ; but only } A \text {. oczlata has hitherto been found } \\
\text { in recent fauna. } \\
\text { A few specimens. } \\
\text { Dredged in Lightning Expedition. A recent form. } \\
\text { These are West Indian forms, and are included in Theco- } \\
\text { psammia, a subgenus, by Pourtales. }\end{array}$ \\
\hline
\end{tabular}

Total species, $\mathrm{x}_{2}$; species absorbed, 9 . Good varieties numerous. Greatest depth from which species were dredged, 705 fathoms. Lowes iemperature of sea at bottom whence corals were dredged, $29^{\circ} 9$. 